\title{
Cardiac and vascular phenotypes in the apolipoprotein E-deficient mouse
}

\author{
Elisardo C Vasquez ${ }^{1,2^{*}}$, Veronica A Peotta ${ }^{3}$, Agata L Gava ${ }^{1,4}$, Thiago MC Pereira ${ }^{5}$ and Silvana S Meyrelles ${ }^{1}$
}

\begin{abstract}
Cardiovascular death is frequently associated with atherosclerosis, a chronic multifactorial disease and a leading cause of death worldwide. Genetically engineered mouse models have proven useful for the study of the mechanisms underlying cardiovascular diseases. The apolipoprotein E-deficient mouse has been the most widely used animal model of atherosclerosis because it rapidly develops severe hypercholesterolemia and spontaneous atherosclerotic lesions similar to those observed in humans. In this review, we provide an overview of the cardiac and vascular phenotypes and discuss the interplay among nitric oxide, reactive oxygen species, aging and diet in the impairment of cardiovascular function in this mouse model.
\end{abstract}

Keywords: Hypercholesterolemia, atherosclerosis, mouse, cardiac function, vascular senescence

\section{Introduction}

Over the last two decades, the mouse has become a very important experimental animal in studies of physiology and a growing number of pathophysiologies due to its easy breeding, short generation time and the availability of inbred strains. The limitations of the small size of the mouse for studying cardiac and vascular hemodynamics and function have been overcome in our and other laboratories due to advances in surgical techniques, as in Borst et al. [1], who described detailed procedures for the analysis of cardiac functional parameters in the mouse.

As a consequence of the progressive advancement of molecular biology techniques, it is possible to knockout and restore endogenous genes or add exogenous genes into the mouse, allowing the development of mouse models for human diseases. Two decades ago, the first gene-targeted murine model of atherosclerosis was created by the inactivation of the apolipoprotein $\mathrm{E}$ (apoE) gene by homologous recombination [2,3]. Among the genetically engineered models, the apoE-deficient $\left(\right.$ apoE $\left.^{-1-}\right)$ mouse is considered to be one of the most relevant models because it develops spontaneous hypercholesterolemia and arterial lesions similar to those observed in humans.

\footnotetext{
* Correspondence: evasquez@pq.cnpq.br

${ }^{1}$ Department of Physiological Sciences, Health Sciences Center, Federal

University of Espirito Santo, Vitoria, ES, Brazil

Full list of author information is available at the end of the article
}

In the apoE $\mathrm{E}^{-1-}$ mouse, most of the plasma cholesterol $(\mathrm{PC})$ is found in the atherogenic lipoprotein fractions, namely the very-low-density lipoprotein (VLDL), intermediate-density lipoprotein (IDL) and low-density lipoprotein (LDL) fractions, and this profile is aggravated by a Western-type diet. On a chow diet, apoE ${ }^{-1-}$ mice exhibit increased total PC ( 8-fold), triglycerides (1.7-fold), VLDL+IDL (18-fold) and LDL (14-fold) compared to C57BL/6J (C57) mice. When fed a Western-type diet, a dramatic increase in the proportions of these lipids is observed in total PC ( 14-fold), particularly in the VLDL+IDL lipoprotein fraction ( 30-fold) [2,4-10].

The combination of the availability of mouse models of atherosclerosis and the technology to perform hemodynamic measurements in mice has enabled the study of the effects of hypercholesterolemia and/or atherosclerosis on cardiac vascular function. In this review, we focus on studies from our laboratory and from other investigators regarding the vascular and cardiac phenotypes in the apoE ${ }^{-/-}$mouse. We also discuss the underlying mechanisms that have been shown to contribute to cardiac and vascular dysfunction in this mouse model.

\section{Vascular phenotypes in apoe ${ }^{-/-}$mice Initiation and progression of atherosclerosis}

The tendency to consider atherosclerosis as the effect of dyslipidemia or inflammation alone has been replaced by a new concept that this disease results from lipid 
disorders, enhanced oxidative stress and inflammation [11-18]. The development of atherosclerosis in conditions of hypercholesterolemia is initiated by the oxidation of lipoproteins such as LDL (oxLDL) in the subendothelial space and dysfunction of endothelial cells. In parallel endothelial cells express vascular and intercellular adhesion molecules (VCAM-1 and ICAM1 ). Consequently, monocytes move into the subendothelial space where they undergo differentiation into macrophages under the influence of stimulating factors. These cells express scavenger receptors that recognize oxLDL and promote their phagocytosis. The degradation of oxLDL in lysosomes is slow, facilitating the formation of foam cells. The pivotal stage of atherogenesis seems to be antigen presentation by macrophages to $\mathrm{T}$ lymphocytes that recognize oxLDL and locally release proinflammatory cytokines such as interleukins (IL-1, 6, 12 and 18) and chemokines such as tumor necrosis factor alpha ( TNF $\alpha)$ and monocyte chemoattractant protein-1 (MCP-1), thereby enhancing the inflammatory cascades. The accumulation and transformation of macrophages into large foam cells form fatty streaks that are characteristics of early atherosclerosis, which progresses into mature atherosclerotic plaques (fibrous caps) in the intima.

The mechanisms and progression of atherosclerosis in the $\mathrm{apoE}^{-/-}$mice have been described before [19-22]. In this model, atherosclerotic lesions are observed throughout the macrovasculature, with the most prevalent sites located in the aortic root, aortic arch, common carotid, superior mesenteric artery and renal and pulmonary arteries. Histopathological studies of the progression of the lesions in the apoE $E^{-/-}$mouse fed a chow diet revealed that the first signs of lesions appear at 6-8 weeks of age, as indicated by the attachment of monocytes to the endothelial cells and a disruption of the subendothelial elastic lamina [21,22]. Lesions containing foam cells and smooth muscle cells are observed at 8-10 weeks and fibrous plaques appear at 15-20 weeks $[21,22]$. The acceleration and severity of atherosclerotic lesions at all stages can be induced by a Western-type diet.

\section{Hemodynamics: endothelial dysfunction}

Recently, we reviewed the potential mechanisms underlying endothelial dysfunction in the $\mathrm{apoE}^{-/-}$mouse and how endothelial dysfunction is influenced by aging, gender and diet [23]. In brief, the conducting vessels of apoE $^{-/-}$mice show an impaired endothelial nitric oxide (NO)-dependent relaxation response to acetylcholine (ACh), which is associated with plaque formation $[6,24,25]$ and aggravated by a Western-type diet $[10,26-28]$ and by aging $[24,29]$. As illustrated in Figure 1 , the main potential mechanism underlying the endothelial dysfunction of $\mathrm{apoE}^{-/-}$mice may be the endothelial NO synthase (eNOS) pathway, due to the uncoupling of eNOS in the endothelium. This uncoupling decreases the bioavailability of $\mathrm{NO}$, increases production of superoxide anion $\left(\cdot \mathrm{O}_{2}^{-}\right)$and generates peroxynitrite $\left(\cdot \mathrm{ONOO}^{-}\right)$, which is associated with the activation of the endothelin-1 (ET-1) system [6,28,30-33]. In resistance vessels, which rarely develop atherosclerotic lesions, impaired endothelial NO-dependent relaxation responses to $\mathrm{ACh}$ have also been observed, primarily in female apoE ${ }^{-/-}$mice $[34,35]$. This effect appears to be mediated by hydrogen peroxide $\left(\mathrm{H}_{2} \mathrm{O}_{2}\right)$ or an endothelium-derived hyperpolarizing factor (EDHF)-like principle agent, increased NADPH oxidase-derived $\cdot \mathrm{O}_{2}{ }^{-}$and ET-1.

Local oxidation of circulating lipoproteins and their incorporation within the vascular endothelium, associated with oxidative processes, plays a pivotal role in the pathogenesis of endothelial dysfunction in the apoE $E^{-/-}$mouse $[6,10]$. The endothelial dysfunction promotes the entry and retention of LDL particles in the artery wall $[36,37]$ enhancing the progression of lesions and creating a vicious cycle. This idea is corroborated by the finding that in vitro treatment of aortas with oxLDL mimicked the endothelial NO dysfunction that was observed in apoE $E^{-/-}$mice [10]. The finding that gene transfer of human paraoxonase 1, which destroys lipid peroxides, into apoE $\mathrm{E}^{-/-}$mice decreased the oxLDL content of the plaques and restored endothelial function [29] corroborates this point of view. Others have shown that treatment of apoE $\mathrm{E}^{-/-}$mice with large empty phospholipid vesicles, which accelerates the reverse pathway of lipid transport from peripheral tissues to the liver, restored endothelium-dependent relaxation, leukocyte adherence, and endothelial expression of VCAM-1 to normal or nearly normal levels [38].

\section{Hemodynamics: arterial blood pressure}

Genetically engineered mouse models have been used to investigate hemodynamics in several cardiovascular diseases, including hypercholesterolemia and atherosclerosis. Several studies, in which blood pressure (BP) was recorded acutely, have shown that BP levels in young-adult (up to 30-week-old) hypercholesterolemic apoE $E^{-/-}$mice fed a standard chow diet or a Westerntype diet are similar to those of control mice [7,31,32,39-45]. Conversely, Yang et al. [46], observed normal resting values of BP in young apoE ${ }^{-/-}$mice but high levels in adult apoE $E^{-/-}$mice, compared with agematched control mice. However, continuous and prolonged recordings of $\mathrm{BP}$ have revealed that apoE $\mathrm{E}^{-/-}$ mice exhibit elevated mean 24-hour BP levels, total abolition of BP circadian cycles and increased BP variability in the very-low-frequency band, which can be improved by the restoration of vagal and NOSmediated regulation with statins [47]. 


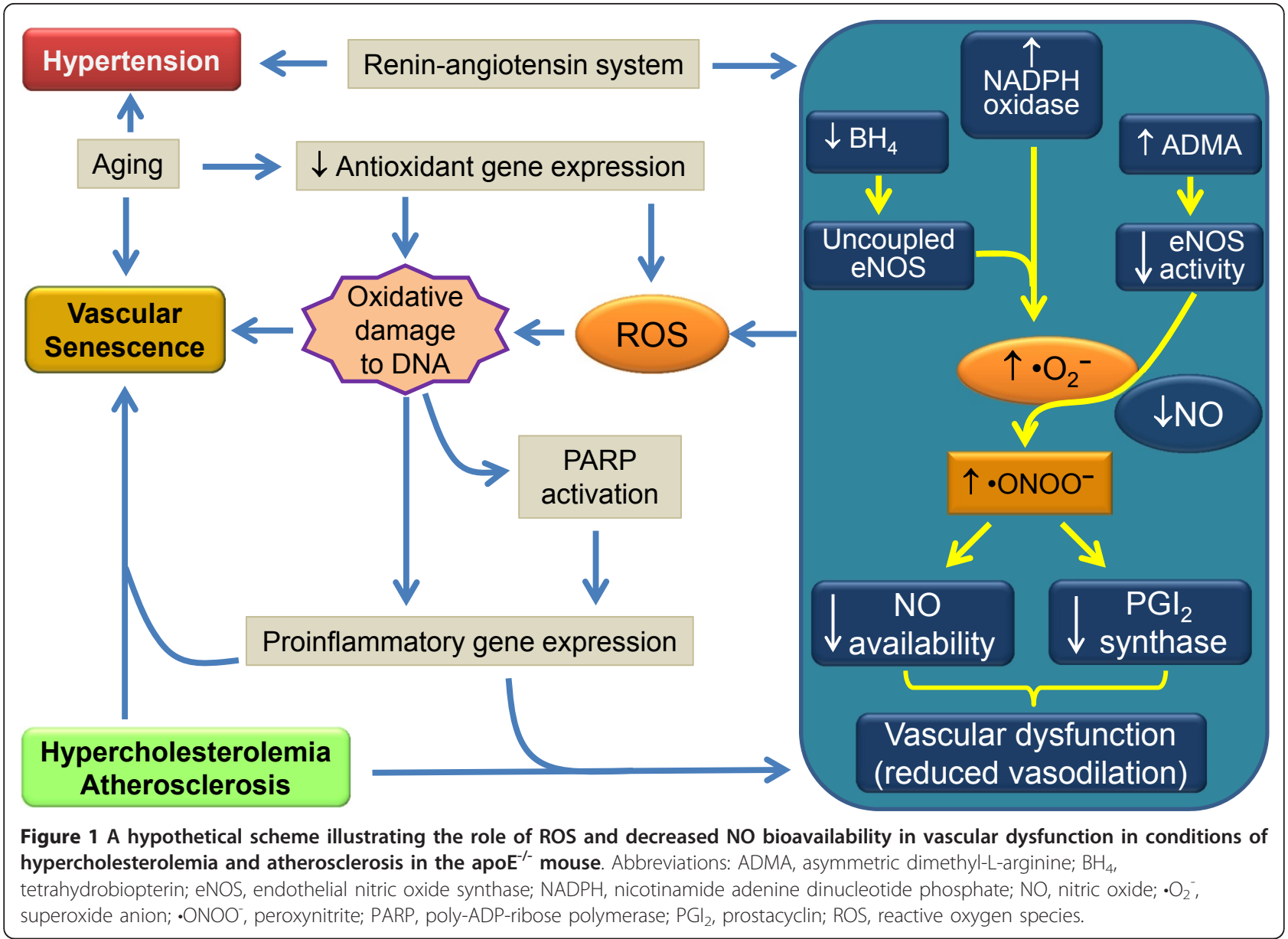

The contribution of high BP to the development of atherosclerosis, and vice-versa, is being actively debated because data involving concurrent measurements of BP and atherosclerosis in mouse models have revealed an association in some studies and a lack of association in others between hypertension and atherosclerosis [48]. One of the first studies showed that subcutaneous infusions of norepinephrine induced increases in BP and in atherosclerotic lesion size in apoE $\mathrm{E}^{-/-}$mice [33]. Considering that angiotensin II (Ang II) accelerates the development of atherosclerosis in both LDL receptor ${ }^{-/}$and $\mathrm{apo}^{-/-}$mice $[33,49,50]$ and that hypercholesterolemia has been associated with activation of the renin-angiotensin system [51,52], the apoE $E^{-1-}$ mouse became an exciting model for evaluating the hemodynamic effects of Ang II in hypercholesterolemic mice (see a hypothetical mechanism in Figure 1). Currently, the suggested mechanisms by which Ang II promotes atherosclerosis include increased oxidative stress, the production of monocyte chemoattractants, and the diapedesis of monocytes [33]. Previous studies of chronic infusions of Ang II in apoE ${ }^{-/-}$mice have led to three conclusions: (a) Ang II-induced atherosclerosis was not associated with an increase in BP [53]; (b) Ang II-induced hypertension was not the direct cause of the profound increase in atherosclerotic lesions [33] because this increase in BP was similar in magnitude to that observed in wild-type control mice [54]; and (c) low doses of Ang II that did not affect BP increased aortic atherosclerotic lesions $[55,56]$. Likewise, it has been shown that pharmacological blockade of the Ang II $\mathrm{AT}_{1}$ receptor in $\mathrm{apoE}^{-/-}$mice or genetic disruption of the $\mathrm{AT}_{1}$ receptor $\left(\mathrm{apoE}^{-1 /} /\right.$ $\mathrm{AT}^{-1-}$ mice) reduces the inflammatory and atherosclerotic lesion process irrespective of BP $[32,57]$. Additionally, long-term Ang (1-7) treatment has been shown to produce vasoprotective and atheroprotective actions in the apoE ${ }^{-1-}$ mouse without direct effects on BP [45]. Conversely, it has been shown that $\mathrm{AT}_{1}$ receptor antagonist treatment lowered BP but had no effect on atherosclerosis [58]. Thus, it appears that the actions of Ang peptides on the pathogenesis of atherosclerosis and on BP occur through independent mechanisms. In our and other laboratories, this issue has been addressed by activating the renin-angiotensin system through partial clipping (stenosis) of the left renal artery (known as two kidney-one clip, or $2 \mathrm{~K} 1 \mathrm{C}$, hypertension) in young 
apoE $\mathrm{E}^{-/-}$mice. In animals with concurrent hypercholesterolemia and activation of the endogenous renin-angiotensin system, the level of arterial hypertension was similar to that observed in normocholesterolemic wildtype C57 mice with high Ang II $[41,42]$. However, an increase in the thickness of the aortic wall is noted to some extent in the hypertensive C57 mouse and especially in the hypercholesterolemic apo: $\mathrm{E}^{-/-}$mouse, and the concurrence of both factors (hypercholesterolemia and hypertension) is observed to exert an additive effect on the aortic wall thickness in the apo: $\mathrm{E}^{-1-}$ mouse [42]. Therefore, it appears that the development of arterial hypertension in atherosclerotic apo: $\mathrm{E}^{-/-}$mice is associated with other concurrent factors, particularly aging, imbalance in NOS/reactive oxygen species (ROS) production and Ang II (see schematic illustration in Figure 1).

\section{Vascular remodeling}

The vessel wall of a plaque-prone region expands to protect the lumen from the expanding plaque (positive remodeling) until the plaque grows so extensively that the outer lumen can no longer compensate and the plaque begins to encroach upon the lumen (negative remodeling) $[59,60]$. In apoE ${ }^{-/-}$mice, positive remodeling has been reported in aortas at both early and late stages of atherosclerosis [42,59,61-63]. However, this observation may not apply for all large vessels as, in carotid arteries, positive remodeling has been reported at the early stages [60], but negative remodeling has been reported in aged animals $[59,60]$. A possible explanation for this discrepancy is that an excessive accumulation of lipids along the internal elastic lamina and within the media results in the death of medial cells and loss of the normal capacity to remodel in the carotid artery [59]. An additional and reasonable factor influencing or determining this difference between the carotid artery and the aorta in aged animals is that the animals were fed a regular diet in the study reporting positive remodeling [60], whereas the animals were fed a Western-type diet in the study reporting negative remodeling [59]. In addition to the lack of compensatory remodeling in the carotid arteries [59], we have observed that aged apoE ${ }^{-/-}$mice show an inward (negative) remodeling in the coronary arteries (unpublished data).

\section{Interplay among lipid and lipoprotein oxidation, DNA} damage and inflammation

Oxidative stress and inflammation are intimately linked to the evolution of atherosclerosis. Oxidative stress originated primarily from ROS in mitochondria can damage cells or components of cells by initiating chemical chain reactions, such as lipid peroxidation, leading to the formation of oxLDL and oxidizing proteins or DNA $[64,65]$. LDL is oxidized in a slow process upon contact with ROS in the sub-intimal space by all major cells of the arterial wall via different mechanisms. ROS induce the oxidation of cholesterol and polyunsaturated fatty acids in LDL. Consequently, lipid peroxidation results in the formation of several products, such as oxysterols and aldehydes, which react with lysine residues of apolipoprotein B (apoB), generating oxLDL [14]. In addition to their metabolic deviation, oxLDL exhibits a large variety of biological and atherogenic properties involved in the activation of inflammatory, mitogenic or proapoptotic pathways, contributing to the progression of atherosclerosis $[14,66]$.

Another cellular target of ROS is DNA; oxidative DNA lesions have been described ranging from base modifications to single- and double-strand breaks [67]. Consequently, excessive oxidative stress-induced DNA damage, which was originally described as the limited ability of a cell to divide, also appears to contribute to the pathogenesis of age-associated vascular disorders $[65,68]$. Recent studies in our laboratory [61] revealed vascular senescence in the aortas of atherosclerotic aged apoE $^{-/-}$mice but not in non-atherosclerotic aged wildtype $\mathrm{C} 57$ mice. This result suggests that in the aorta the occurrence of vascular senescence in aging may be related to the development of vascular disease, and this phenomenon may be the cause of the endothelial dysfunction observed in this murine model. Based on the observation that the induction of senescence in human aortic endothelial cells by the inhibition of telomere function results in decreased eNOS activity [69,70], studies with the atherosclerotic apoE $\mathrm{E}^{-/-}$mouse may provide an opportunity to evaluate and understand the interaction of vascular endothelial dysfunction and vascular senescence. We postulated that the renin-angiotensin system plays a dual role, contributing additively with ROS to DNA damage and additively with aging to arterial hypertension.

Oxidative damage to DNA in atherosclerosis also modifies other biochemical and regulatory pathways such as the overexpression of poly(ADP-ribose) polymerase (PARP-1) [71,72]. PARP-1 is a nuclear enzyme that recognizes and is activated by DNA strand breaks and is thus involved in DNA damage response pathways; simultaneously, PARP-1 may induce cell dysfunction or necrosis by depleting cellular energy pools [73]. Pacher et al. [74] reported that the activation of PARP-1 is associated with hypertension and aging but not with atherosclerosis. In contrast, other investigators [71,75] have shown that functional alterations in the endothelium of the apo: $\mathrm{E}^{-/-}$mouse are dependent on the activation of PARP-1 in endothelial cells. This activation leads to proinflammatory gene expression and thus contributes to the vascular senescence and endothelial dysfunction that are observed in atherosclerosis. Moreover, pharmacological blockade and genetic manipulations 
have demonstrated that endogenous PARP-1 is required for atherogenesis in the apoE $\mathrm{E}^{-1-}$ mouse and functions by increasing the expression of adhesion molecules upon endothelial activation, enhancing inflammation, and inducing features of plaque vulnerability. Thus, inhibition of PARP1 may represent a promising therapeutic target in atherosclerosis [73]. Figure 1 illustrates the interplay among ROS, oxidative damage to DNA, the renin-angiotensin system, vascular senescence and atherosclerosis in the apoE $\mathrm{E}^{-/-}$mouse.

Atherosclerosis is a chronic disease, and whether it is initiated and/or aggravated by dyslipidemia depends on the contribution of oxidative stress and proinflammatory mediators. Thus, the impact of these contributors on the development of atherosclerotic lesions may reveal new treatment options, independent of serum lipids reduction. Recent studies in apoE ${ }^{-/-}$mice have demonstrated a reduction in atherosclerosis development using an immunodeficiency strategy [20], low dose of the phytochemical tetrahydrocannabinol [76], antioxidant NAcetylcysteine [77], PARP inhibition [73] or mononuclear cell therapy [63].

In relation to cell therapy, there is consistent evidence [78] that the atherosclerotic process initiated by endothelial death results in the subsequent replacement of the affected cells by endothelial progenitor cells; in addition, the evidence indicates that the cellular repair of ongoing vascular injury is mediated by progenitor cells. Indeed, treatment with spleen-derived mononuclear cells increases vascular NOS activity and restores endothelium-dependent relaxation in the aortas of $\mathrm{apoE}^{-/-}$mice [79]. Moreover, mononuclear cell therapy in apo: $\mathrm{E}^{-1-}$ mice results in the homing of endothelial progenitor cells, a decrease in oxidative stress and an upregulation of eNOS protein expression [63], which indicates that cell therapy is a promising tool for the restoration of endothelial function and the prevention of atherosclerosis development, independent of a reduction in serum lipids.

\section{Cardiac phenotypes in apoe ${ }^{-/-}$mice Resting $H R$}

The mouse has a high resting heart rate (HR), which is related to its high metabolism. Hemodynamic measurements have shown that the resting HR in the conscious wild-type C57 mouse ranges from 520 to $650 \mathrm{bpm}$ $[42,80,81]$. Similar values have been observed with acute measurements in conscious apoE $E^{-/-}$mice $[32,41,42$, $46,80,82,83]$. Interestingly, some studies have shown that $\mathrm{HR}$ is preserved even when the BP is high in $\mathrm{apoE}^{-/-}$ mice fed either a standard chow diet [46] or a Westerntype diet [84]. However, others have evaluated HR by continuous recording over 24 hours and observed a significantly increased mean HR and a total abolition of its circadian cycles in the apoE $\mathrm{E}^{-/-}$mouse compared with wild-type control mice [47]. Moreover, apoE ${ }^{-1-}$ mice exhibited decreased HR variability associated with abnormal neurohumoral control of HR and a defective parasympathetic drive to the heart, which were further exacerbated under a high-fat diet regimen [47,71]. It has also been observed that chronic treatment of apo $\mathrm{E}^{-/-}$ mice with a statin reduced their HRs to control levels and restored their circadian variations, despite persistent elevations in PC levels [47]. Although further studies are needed to clarify the mechanisms involved in the abnormal cardiac rhythm in the apoE $\mathrm{E}^{-/-}$mouse, there is evidence that the imbalance in $\mathrm{NO} / \cdot \mathrm{O}_{2}{ }^{-}$production may play a pivotal role $[47,71]$.

\section{Cardiac hypertrophy}

Cardiac hypertrophy is also an important parameter to evaluate because it can be related to cardiac dysfunction (see the illustration in Figure 2). In studies with apoE $\mathrm{E}^{-1-}$ mice in our laboratory, we regularly evaluate cardiac hypertrophy, which can be determined by measuring the cardiac weight-to-body weight ratio $[42,81]$. In apoE ${ }^{-/-}$

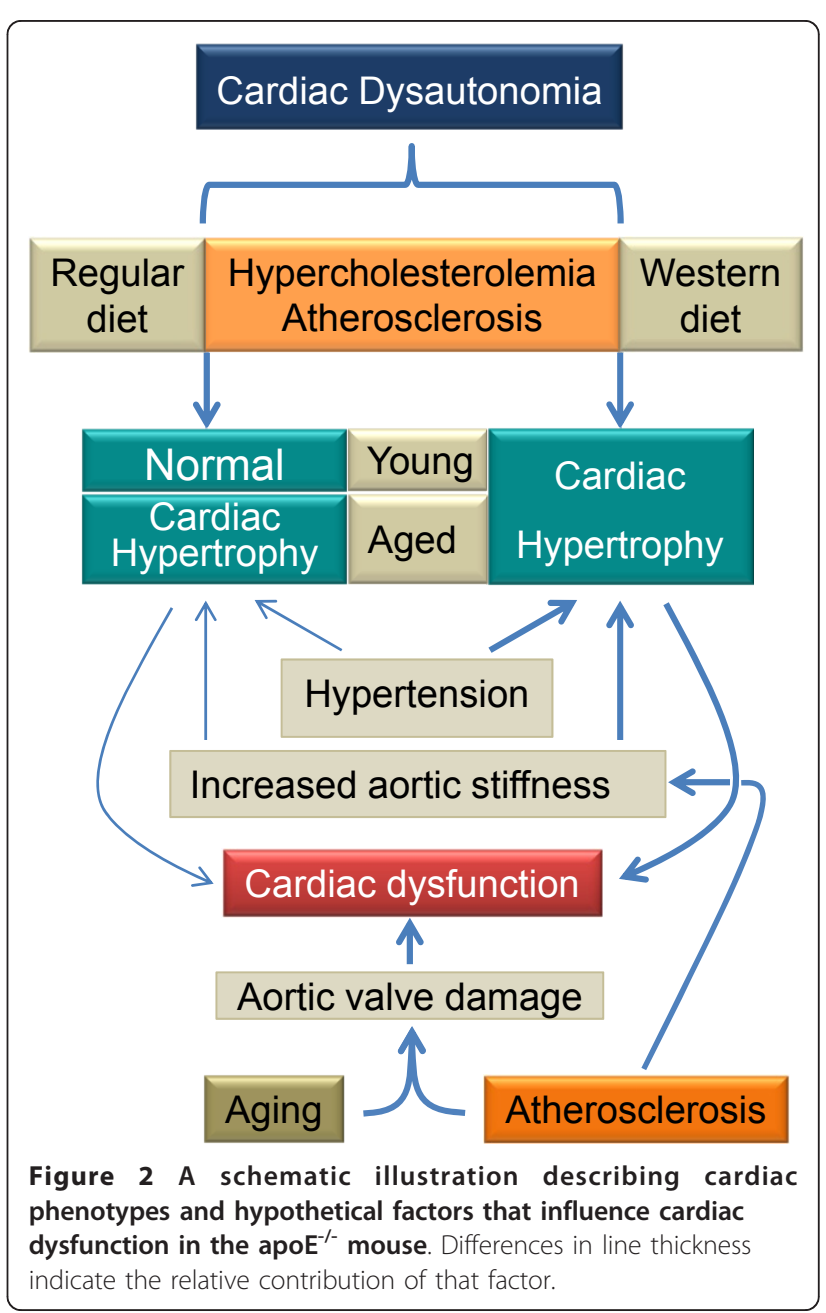


mice fed a normal diet, the cardiac weight has been reported as normal at different ages in several studies $[42,46,61,83,85]$, but others have observed myocardial hypertrophy in adult [46] and aged [80,85] animals. However, there are some controversies regarding the possible factors determining cardiac hypertrophy in aged animals. For example, it has been reported that the animals were normotensive and that the cardiac hypertrophy could be related to an elevated blood velocity and wave reflections close to the heart [80]. On the contrary, others reported both hypertension and myocardial hypertrophy in aged apoE $\mathrm{E}^{-/-}$mice [46]. In this case, cardiac hypertrophy could be the consequence of an increased afterload, as has been observed in non-atherosclerotic hypertensive mice $[42,81]$. Importantly, the cardiac hypertrophy in response to the aortic coarctationinduced pressure overload is higher in apoE $\mathrm{E}^{-/-}$mice than in C57 mice [83], leading to the hypothesis that apolipoprotein $\mathrm{E}$ may play an important role in modulating cardiac hypertrophy, even in wild-type mice. On a Western-type diet, apoE ${ }^{-1-}$ mice show cardiac hypertrophy that is worsened with aging [86]. Thus, despite certain controversies, studies have provided important evidence that the apo: ${ }^{-1-}$ mouse develops cardiac hypertrophy, which appears to be influenced by several factors, including increased aortic stiffness, arterial hypertension, and a Western-type diet combined with the aging process (see the schematic illustration in Figure 2).

\section{Cardiac function}

Technical progress has resulted in the ability to perform arterial and cardiac catheterization; in vivo imaging in the mouse is then utilized, with the aim of understanding cardiac function and dysfunction. Recently, Borst et al. [1] published an extraordinary review about methods employed for the induction and analysis of myocardial infarction in mice. However, murine models of atherosclerosis have coronary arteries that are relatively resistant to the consequences of atherosclerosis and usually do not exhibit myocardial infarction or other cardinal features of human coronary heart disease or reduced lifespan [22,87]. Hemodynamic analysis in young apoE ${ }^{-1-}$ mice fed a standard chow diet shows normal left ventricular end diastolic pressure and systolic pressure, cardiac output, fractional shortening, and other cardiac functional parameters $[87,88]$. Some studies show that feeding young animals an atherogenic diet does not seem to affect cardiac function [25], and these animals rarely show occlusive coronary artery disease and myocardial infarction under this diet [89]. However, others have reported changes in the left ventricular geometry, elevated cardiac outflow velocities, decreased distensibility of the ascending aorta and increased pulse-wave velocity, even when apoE ${ }^{-/-}$mice are fed a regular chow diet $[80,90,91]$. In aged apoE ${ }^{-/-}$mice, it has been reported that increased cardiac afterload due to increased aortic stiffening appears to contribute to a reduced cardiac reserve, indicating a reduced cardiac functional reserve in this animal [92].

Interestingly, while recently measuring the diameter of the aorta through contrast angiography, we incidentally observed aortic regurgitation associated with a larger $\left(\sim 3\right.$-fold) valvular thickness in elderly apoE ${ }^{-/-}$mice [61]. Aortic regurgitation was observed in the elderly (hypercholesterolemic and atherosclerotic) apoE $\mathrm{E}^{-/-}$ mouse but neither in the young (hypercholesterolemic) apoE ${ }^{-/-}$mouse nor in the elderly C57 control mouse (normocholesterolemic), indicating that this cardiac dysfunction is dependent on the concurrence of hypercholesterolemia and aging [61]. In that study, the authors showed that the aortic valve damage was characterized by diffuse acellularity and myxoid thickening of the spongy layer, as well as valve fibrosis with dense collagen formation in the apoE $\mathrm{E}^{-/-}$mouse.

Among the animal models of heart failure, the major limitation of the apoE $E^{-1-}$ mouse is the infrequency of coronary plaques and thrombosis, two common complications of human atherosclerosis, as recently reviewed [93]. Cardiac function has also been evaluated by interbreeding apoE ${ }^{-/-}$and renin-angiotensinogen transgenic $\left(\mathrm{R}^{+} \mathrm{A}^{+}\right)$mice; in this animal model, heart failure develops with aging, as indicated by the decreased ejection fraction and increased lung weight in aged mice [94].

\section{Conclusion}

Since its creation two decades ago, the apoE $\mathrm{E}^{-/-}$mouse, which spontaneously develops hypercholesterolemia and vascular atherosclerotic lesions on a regular chow diet, has greatly contributed to the understanding of the atherosclerosis disease process. Excess production of ROS responding to internal or environmental stress triggers several signaling steps culminating with lipid oxidation, DNA damage, senescence and production of proinflammatory substances. The renin-angiotensin system also appears to play an important role, contributing additively with ROS to changes in vascular function. Long-term recordings of $\mathrm{HR}$ and $\mathrm{BP}$ show evidence that apo: ${ }^{-/-}$mice exhibit hypertension and tachycardia and abolition of their circadian cycles, primarily when under the influence of aging and a Western-type diet. Studies also provide evidence of impaired cardiac function in $\mathrm{apoE}^{-/-}$mice, which is related to and/or aggravated by aging and a Western-type diet. Therefore, the studies in apoE $^{-1-}$ mice have contributed new insights into the mechanisms underlying the cardiac and vascular dysfunction that occur in this chronic inflammatory disease. 


\section{Acknowledgements}

ECV and SSM are supported by the National Council for the Development of Science and Technology (CNPq, Ref. 302113/2008-8 Grant) and the State Agency for the Development of Science and Technology (FAPES, Ref. FAPES/ PRONEX 012/2009).

\section{Author details}

'Department of Physiological Sciences, Health Sciences Center, Federal University of Espirito Santo, Vitoria, ES, Brazil. 'Emescam School of Health Sciences, Vitoria, ES, Brazil. ${ }^{3}$ The University of lowa, lowa City, IA, USA. ${ }^{4}$ Biotechnology Graduate Program, Health Sciences Center, Federal University of Espirito Santo, Vitoria, ES, Brazil. ${ }^{5}$ Federal Institute of Education, Science and Technology (IFES), Vila Velha, ES, Brazil.

\section{Authors' contributions}

ECV, VAP, ALG, TMCP and SSM equally conceived and prepared this review. All of the authors read and approved the final manuscript.

\section{Competing interests}

The authors declare that they have no competing interests.

Received: 14 December 2011 Accepted: 13 February 2012

Published: 13 February 2012

\section{References}

1. Borst O, Ochmann C, Schönberger T, Jacoby C, Stellos K, Seizer P, Flögel U, Lang F, Gawaz M: Methods employed for induction and analysis of experimental myocardial infarction in mice. Cell Physiol Biochem 2011, 28:1-12

2. Plump AS, Smith JD, Hayek T, Aalto-Setälä K, Walsh A, Verstuyft JG, Rubin EM, Breslow JL: Severe hypercholesterolemia and atherosclerosis in apolipoprotein E-deficient mice created by homologous recombination in ES cells. Cell 1992, 71(2):343-53.

3. Piedrahita JA, Zhang SH, Hagaman JR, Oliver PM, Maeda N: Generation of mice carrying a mutant apolipoprotein $\mathrm{E}$ gene inactivated by gene targeting in embryonic stem cells. Proc Natl Acad Sci USA 1992, 89(10):4471-5.

4. Zhang SH, Reddick RL, Burkey B, Maeda N: Diet-induced atherosclerosis in mice heterozygous and homozygous for apolipoprotein $\mathrm{E}$ gene disruption. J Clin Invest 1994, 94(3):937-45

5. Bourassa PA, Milos PM, Gaynor BJ, Breslow JL, Aiello RJ: Estrogen reduces atherosclerotic lesion development in apolipoprotein E-deficient mice. Proc Natl Acad Sci USA 1996, 93(19):10022-7

6. Bonthu S, Heistad DD, Chappell DA, Lamping KG, Faraci FM: Atherosclerosis, vascular remodeling, and impairment of endotheliumdependent relaxation in genetically altered hyperlipidemic mice. Arterioscler Thromb Vasc Biol 1997, 17(11):2333-40.

7. d'Uscio LV, Barton M, Shaw S, Lüscher TF: Chronic ET(A) receptor blockade prevents endothelial dysfunction of small arteries in apolipoprotein E-deficient mice. Cardiovasc Res 2002, 53(2):487-95.

8. Surra JC, Guillén N, Arbonés-Mainar JM, Barranquero C, Navarro MA, Arnal C, Orman I, Segovia JC, Osada J: Sex as a profound modifier of atherosclerotic lesion development in apolipoprotein E-deficient mice with different genetic backgrounds. J Atheroscler Thromb 2010, 17(7):712-21.

9. Nakashima Y, Plump AS, Raines EW, Breslow JL, Ross R: ApoE-deficient mice develop lesions of all phases of atherosclerosis throughout the arterial tree. Arterioscler Thromb 1994, 14(1):133-40.

10. Jiang F, Gibson AP, Dusting GJ: Endothelial dysfunction induced by oxidized low-density lipoproteins in isolated mouse aorta: a comparison with apolipoprotein-E deficient mice. Eur J Pharmacol 2001, 424(2):141-9.

11. Ross R: The pathogenesis of atherosclerosis: a perspective for the 1990s. Nature 1993, 362:801-9.

12. Hansson GK: Inflammation, atherosclerosis, and coronary artery disease. N Engl J Med 2005, 352:1685-95.

13. Stoll G, Bendszus M: Inflammation and atherosclerosis: novel insights into plaque formation and destabilization. Stroke 2006, 37(7):1923-32

14. Negre-Salvayre A, Coatrieux C, Ingueneau C, Salvayre R: Advanced lipid peroxidation end products in oxidative damage to proteins. Potential role in diseases and therapeutic prospects for the inhibitors. $\mathrm{Br} J$ Pharmacol 2008, 153(1):6-20.
15. Getz GS: Overview of murine atherosclerosis series. Curr Drug Targets 2007, 8:1144-49.

16. Weber C, Zernecke A, Libby P: The multifaceted contributions of leukocyte subsets to atherosclerosis: lessons from mouse models. Nat Rev Immunol 2008, 8:802-15.

17. Steinberg D: Atherogenesis in perspective: hypercholesterolemia and inflammation as partners in crime. Nat Med 2002, 8:1211-7.

18. Jawień J: New insights into immunological aspects of atherosclerosis. Pol Arch Med Wewn 2008, 118(3):127-31.

19. Shemesh S, Kamari Y, Shaish A, Olteanu S, Kandel-Kfir M, Almog T, Grosskopf I, Apte RN, Harats D: Interleukin-1 receptor type-1 in nonhematopoietic cells is the target for the pro-atherogenic effects of interleukin-1 in apoE-deficient mice. Atherosclerosis 2012.

20. Zhou X, Nicoletti A, Elhage R, Hansson GK: Transfer of CD4(+) T cells aggravates atherosclerosis in immunodeficient apolipoprotein $\mathrm{E}$ knockout mice. Circulation 2000, 102:2919-22.

21. Nakashima Y, Plump AS, Raines EW, Breslow JL, Ross R: ApoE-deficient mice develop lesions of all phases of atherosclerosis throughout the arterial tree. Arterioscler Thromb 1994, 14(1):133-40.

22. Coleman R, Hayek T, Keidar S, Aviram M: A mouse model for human atherosclerosis: long-term histopathological study of lesion development in the aortic arch of apolipoprotein E-deficient (E0) mice. Acta Histochem 2006, 108(6):415-24.

23. Meyrelles SS, Peotta VA, Pereira TM, Vasquez EC: Endothelial dysfunction in the apolipoprotein E-deficient mouse: insights into the influence of diet, gender and aging. Lipids Health Dis 2011, 10:211.

24. Crauwels HM, Van Hove CE, Holvoet P, Herman AG, Bult H: Plaqueassociated endothelial dysfunction in apolipoprotein E-deficient mice on a regular diet. Effect of human apolipoprotein Al. Cardiovasc Res 2003, 59(1):189-99.

25. Johansson ME, Hägg U, Wikström J, Wickman A, Bergström G, Gan LM: Haemodynamically significant plaque formation and regional endothelial dysfunction in cholesterol-fed $\mathrm{ApoE}^{-1-}$ mice. Clin Sci (Lond) 2005, 108(6):531-8.

26. Deckert V, Lizard G, Duverger N, Athias A, Palleau V, Emmanuel F, Moisant M, Gambert P, Lallemant C, Lagrost L: Impairment of endothelium-dependent arterial relaxation by high-fat feeding in ApoEdeficient mice: toward normalization by human ApoA-I expression. Circulation 1999, 100(11):1230-5.

27. Yaghoubi M, Oliver-Krasinski J, Cayatte AJ, Cohen RA: Decreased sensitivity to nitric oxide in the aorta of severely hypercholesterolemic apolipoprotein E-deficient mice. J Cardiovasc Pharmacol 2000, 36(6):751-7.

28. d'Uscio LV, Baker TA, Mantilla CB, Smith L, Weiler D, Sieck GC, Katusic ZS: Mechanism of endothelial dysfunction in apolipoprotein E-deficient mice. Arterioscler Thromb Vasc Biol 2001, 21(6):1017-22.

29. Guns PJ, Van Assche T, Verreth W, Fransen P, Mackness B, Mackness M, Holvoet $P$, Bult $H$ : Paraoxonase 1 gene transfer lowers vascular oxidative stress and improves vasomotor function in apolipoprotein E-deficient mice with pre-existing atherosclerosis. Br J Pharmacol 2008, 153(3):508-16.

30. Laursen JB, Somers M, Kurz S, McCann L, Warnholtz A, Freeman BA, Tarpey M, Fukai T, Harrison DG: Endothelial regulation of vasomotion in apoE-deficient mice: implications for interactions between peroxynitrite and tetrahydrobiopterin. Circulation 2001, 103(9):1282-8.

31. Barton M, Haudenschild CC, d'Uscio LV, Shaw S, Münter K, Lüscher TF: Endothelin $\mathrm{ET}_{\mathrm{A}}$ receptor blockade restores NO-mediated endothelial function and inhibits atherosclerosis in apolipoprotein E-deficient mice. Proc Natl Acad Sci USA 1998, 95(24):14367-72.

32. Wassmann S, Czech T, van Eickels M, Fleming I, Böhm M, Nickenig G: Inhibition of diet-induced atherosclerosis and endothelial dysfunction in apolipoprotein E/angiotensin II type 1A receptor double-knockout mice. Circulation 2004, 110(19):3062-7.

33. Weiss D, Kools JJ, Taylor WR: Angiotensin II-induced hypertension accelerates the development of atherosclerosis in apoE-deficient mice. Circulation 2001, 103(3):448-54.

34. Cola MS, Gava AL, Meyrelles SS, Vasquez EC: Endothelial dysfunction of resistance vessels in female apolipoprotein E-deficient mice. Lipids Health Dis 2010, 9:51.

35. Kitayama J, Faraci FM, Lentz SR, Heistad DD: Cerebral vascular dysfunction during hypercholesterolemia. Stroke 2007, 38(7):2136-41. 
36. Tabas I, Williams KJ, Boren J: Subendothelial lipoprotein retention as the initiating process in atherosclerosis: update and therapeutic implications. Circulation 2007, 116:1832-44.

37. Libby P, Ridker PM, Hansson GK: Progress and challenges in translating the biology of atherosclerosis. Nature 2011, 473:317-25.

38. Williams KJ, Scalia R, Mazany KD, Rodrigueza W, Lefer AM: Rapid restoration of normal endothelial functions in genetically hyperlipidemic mice by a synthetic mediator of reverse lipid transport. Arterioscler Thromb Vasc Biol 2000, 20(4):1033-9.

39. Meyrelles SS, Chapleau MW: Impaired carotid occlusion reflex in apoE deficient mice and its reversal by gene transfer to carotid sinus. J Hypertens 2000, 18(Suppl 4):S202.

40. Gervais M, Pons S, Nicoletti A, Cosson C, Giudicelli JF, Richer C: Fluvastatin prevents renal dysfunction and vascular NO deficit in apolipoprotein E-deficient mice. Arterioscler Thromb Vasc Biol 2003, 23(2):183-9.

41. Arruda RM, Peotta VA, Meyrelles SS, Vasquez EC: Evaluation of vascular function in apolipoprotein $E$ knockout mice with angiotensin-dependent renovascular hypertension. Hypertension 2005, 46(4):932-6.

42. Nogueira BV, Peotta VA, Meyrelles SS, Vasquez EC: Evaluation of aortic remodeling in apolipoprotein E-deficient mice and renovascular hypertensive mice. Arch Med Res 2007, 38(8):816-21.

43. Stapleton PA, Goodwill AG, James ME, Frisbee JC: Altered mechanisms of endothelium-dependent dilation in skeletal muscle arterioles with genetic hypercholesterolemia. Am J Physiol Regul Integr Comp Physiol 2007 293(3):R1110-9.

44. Custodis F, Baumhäkel M, Schlimmer N, List F, Gensch C, Böhm M, Laufs U: Heart rate reduction by ivabradine reduces oxidative stress, improves endothelial function, and prevents atherosclerosis in apolipoprotein Edeficient mice. Circulation 2008, 117(18):2377-87.

45. Tesanovic S, Vinh A, Gaspari TA, Casley D, Widdop RE: Vasoprotective and atheroprotective effects of angiotensin (1-7) in apolipoprotein Edeficient mice. Arterioscler Thromb Vasc Biol 2010, 30(8):1606-13.

46. Yang R, Powell-Braxton L, Ogaoawara AK, Dybdal N, Bunting S, Ohneda O, Jin H: Hypertension and endothelial dysfunction in apolipoprotein $\mathrm{E}$ knockout mice. Arterioscler Thromb Vasc Biol 1999, 19(11):2762-8.

47. Pelat M, Dessy C, Massion P, Desager JP, Feron O, Balligand JL: Rosuvastatin decreases caveolin-1 and improves nitric oxide-dependent heart rate and blood pressure variability in apolipoprotein $\mathrm{E}^{-/-}$mice in vivo. Circulation 2003, 107(19):2480-6.

48. Lu H, Cassis LA, Daugherty A: Atherosclerosis and arterial blood pressure in mice. Curr Drug Targets 2007, 8(11):181-9.

49. Daugherty A, Manning MW, Cassis LA: Antagonism of AT2 receptors augments angiotensin II-induced abdominal aortic aneurysms and atherosclerosis. Br J Pharmacol 2001, 134(4):865-70.

50. Bruemmer D, Collins AR, Noh G, Wang W, Territo M, Arias-Magallona S, Fishbein MC, Blaschke F, Kintscher U, Graf K, Law RE, Hsueh WA: Angiotensin II-accelerated atherosclerosis and aneurysm formation is attenuated in osteopontin-deficient mice. J Clin Invest 2003, 112(9):1318-31.

51. Ferrario CM, Smith R, Levy $P$, Strawn W: The hypertension-lipid connection: insights into the relation between angiotensin II and cholesterol in atherogenesis. Am J Med Sci 2002, 323(1):17-24.

52. Daugherty A, Rateri DL, Lu H, Inagami T, Cassis LA: Hypercholesterolemia stimulates angiotensin peptide synthesis and contributes to atherosclerosis through the AT1A receptor. Circulation 2004, 110(25):3849-57.

53. Daugherty A, Manning MW, Cassis LA: Angiotensin II promotes atherosclerotic lesions and aneurysms in apolipoprotein E-deficient mice. J Clin Invest 2000, 105:1605-12.

54. Vinh A, Widdop RE, Drummond GR, Gaspari TA: Chronic angiotensin IV treatment reverses endothelial dysfunction in ApoE-deficient mice. Cardiovasc Res 2008, 77(1):178-87.

55. Ayabe N, Babaev VR, Tang Y, Tanizawa T, Fogo AB, Linton MF, Ichikawa I, Fazio S, Kon V: Transiently heightened angiotensin II has distinct effects on atherosclerosis and aneurysm formation in hyperlipidemic mice. Atherosclerosis 2006, 184(2):312-21.

56. Nobuhiko A, Suganuma E, Babaev VR, Fogo A, Swift LL, Linton MF, Fazio S, Ichikawa I, Kon V: Angiotensin II amplifies macrophage-driven atherosclerosis. Arterioscler Thromb Vasc Biol 2004, 24(11):2143-8.

57. Cheng XW, Song H, Sasaki T, Hu L, Inoue A, Bando YK, Shi GP, Kuzuya M, Okumura K, Murohara T: Angiotensin type 1 receptor blocker reduces intimal neovascularization and plaque growth in apolipoprotein Edeficient mice. Hypertension 2011, 57(5):981-9.

58. Zhou Y, Chen R, Catanzaro SE, Hu L, Dansky HM, Catanzaro DF: Differential effects of angiotensin II on atherogenesis at the aortic sinus and descending aorta of apolipoprotein E-deficient mice. Am J Hypertens 2005, 18(4 Pt 1):486-92.

59. Seo HS, Lombardi DM, Polinsky P, Powell-Braxton L, Bunting S, Schwartz SM, Rosenfeld ME: Peripheral vascular stenosis in apolipoprotein E-deficient mice: potential roles of lipid deposition, medial atrophy, and adventitial inflammation. Arterioscler Thromb Vasc Biol 1997, 17:3593-3601.

60. Walker M, Campbell BR, Azer K, Tong C, Fang K, Cook JJ, Forrest MJ, Kempadoo K, Wright SD, Saltzman JS, Maclntyre E, Hargreaves R: A novel 3dimensional micro-ultrasound approach to automated measurement of carotid arterial plaque volume as a biomarker for experimental atherosclerosis. Atherosclerosis 2009, 204(1):55-65.

61. Pereira TM, Nogueira BV, Lima LC, Porto ML, Arruda JA, Vasquez EC, Meyrelles SS: Cardiac and vascular changes in elderly atherosclerotic mice: the influence of gender. Lipids Health Dis 2010, 9:87.

62. Bentzon JF, Pasterkamp G, Falk E: Expansive remodeling is a response of the plaque-related vessel wall in aortic roots of ApoE-deficient mice: an experiment of nature. Arterioscler Thromb Vasc Biol 2003, 23:257-62.

63. Porto ML, Lima LC, Pereira TM, Nogueira BV, Tonini CL, Campagnaro BP, Meyrelles SS, Vasquez EC: Mononuclear cell therapy attenuates atherosclerosis in apoE KO mice. Lipids Health Dis 2011, 10:155.

64. Pashkow FJ: Oxidative stress and inflammation in heart disease: do antioxidants have a role in treatment and/or prevention? Int J Inflam 2011, 2011:514623.

65. Minamino T, Komuro I: Vascular cell senescence: contribution to atherosclerosis. Circ Res 2007, 100(1):15-26.

66. Uchida K, Itakura K, Kawakishi S, Hiai H, Toyokuni S, Stadtman ER: Characterization of epitopes recognized by 4-hydroxy-2-nonenal specific antibodies. Arch Biochem Biophys 1995, 324:241-8.

67. Hasty P, Campisi J, Hoeijmakers J, van Steeg H, Vijg J: Aging and genome maintenance: lessons from the mouse? Science 2003, 299:1355-9.

68. Ota H, Eto M, Ogawa S, lijima K, Akishita M, Ouchi Y: SIRT1/eNOS axis as a potential target against vascular senescence, dysfunction and atherosclerosis. J Atheroscler Thromb 2010, 17(5):431-5.

69. Minamino T, Miyauchi H, Yoshida T, Ishida Y, Yoshida H, Komuro I: Endothelial cell senescence in human atherosclerosis: role of telomere in endothelial dysfunction. Circulation 2002, 105(13):1541-4.

70. Matsushita H, Chang E, Glassford AJ, Cooke JP, Chiu CP, Tsao PS: eNOS activity is reduced in senescent human endothelial cells: Preservation by hTERT immortalization. Circ Res 2001, 89(9):793-8.

71. Hans CP, Feng Y, Naura AS, Zerfaoui M, Rezk BM, Xia H, Kaye AD, Matrougui K, Lazartigues E, Boulares AH: Protective effects of PARP-1 knockout on dyslipidemia-induced autonomic and vascular dysfunction in ApoE mice: effects on eNOS and oxidative stress. PLOS One 2009, 4(10):e7430

72. Martinet W, Knaapen MW, De Meyer GR, Herman AG, Kockx MM: Elevated levels of oxidative DNA damage and DNA repair enzymes in human atherosclerotic plaques. Circulation 2002, 106(8):927-32.

73. von Lukowicz T, Hassa PO, Lohmann C, Borén J, Braunersreuther V, Mach F, Odermatt B, Gersbach M, Camici GG, Stähli BE, Tanner FC, Hottiger MO, Lüscher TF, Matter CM: PARP1 is required for adhesion molecule expression in atherogenesis. Cardiovasc Res 2008, 78(1):158-66.

74. Pacher P, Mabley JG, Soriano FG, Liaudet L, Szabó C: Activation of poly (ADP-ribose) polymerase contributes to the endothelial dysfunction associated with hypertension and aging. Int J Mol Med 2002, 9(6):659-64

75. Benkö R, Pacher P, Vaslin A, Kollai M, Szabó C: Restoration of the endothelial function in the aortic rings of apolipoprotein $E$ deficient mice by pharmacological inhibition of the nuclear enzyme poly(ADPribose) polymerase. Life Sci 2004, 75(10):1255-61.

76. Steffens S, Veillard NR, Arnaud C, Pelli G, Burger F, Staub C, Karsak M, Zimmer A, Frossard JL, Mach F: Low dose oral cannabinoid therapy reduces progression of atherosclerosis in mice. Nature 2005, 434:782-6.

77. Shimada K, Murayama T, Yokode M, Kita T, Uzui H, Ueda T, Lee JD, Kishimoto C: $\mathrm{N}$-acetylcysteine reduces the severity of atherosclerosis in apolipoprotein E-deficient mice by reducing superoxide production. Circ J 2009, 73(7):1337-41.

78. $\mathrm{Xu} \mathrm{Q}$ : The impact of progenitor cells in atherosclerosis. Nat Clin Pract Cardiovasc Med 2006, 3(2):94-101. 
79. Wassmann S, Werner N, Czech T, Nickenig G: Improvement of endothelial function by systemic transfusion of vascular progenitor cells. Circ Res 2006, 99(8):e74-83.

80. Hartley CJ, Reddy AK, Madala S, Martin-McNulty B, Vergona R, Sullivan ME, Halks-Miller M, Taffet GE, Michael LH, Entman ML, Wang YX: Hemodynamic changes in apolipoprotein E-knockout mice. Am J Physiol Heart Circ Physiol 2000, 279(5):H2326-34.

81. Peotta VA, Gava AL, Vasquez EC, Meyrelles SS: Evaluation of baroreflex control of heart rate in renovascular hypertensive mice. Can J Physiol Pharmacol 2007, 85(8):761-6.

82. Braun A, Trigatti BL, Post MJ, Sato K, Simons M, Edelberg JM, Rosenberg RD, Schrenzel M, Krieger M: Loss of SR-BI expression leads to the early onset of occlusive atherosclerotic coronary artery disease, spontaneous myocardial infarctions, severe cardiac dysfunction, and premature death in apolipoprotein E-deficient mice. Circ Res 2002, 90(3):270-6.

83. Wu JH, Hagaman J, Kim S, Reddick RL, Maeda N: Aortic constriction exacerbates atherosclerosis and induces cardiac dysfunction in mice lacking apolipoprotein E. Arterioscler Thromb Vasc Biol 2002, 22(3):469-75.

84. Kuhlencordt PJ, Gyurko R, Han F, Scherrer-Crosbie M, Aretz TH, Hajjar R, Picard MH, Huang PL: Accelerated atherosclerosis, aortic aneurysm formation, and ischemic heart disease in apolipoprotein E/endothelial nitric oxide synthase double-knockout mice. Circulation 2001, 104(4):448-54.

85. Wang YX: Cardiovascular functional phenotypes and pharmacological responses in apolipoprotein E deficient mice. Neurobiol Aging 2005, 26(3):309-16.

86. Qin $Y W$, Ye P, He JQ, Sheng L, Wang LY, Du J: Simvastatin inhibited cardiac hypertrophy and fibrosis in apolipoprotein E-deficient mice fed a "Western-style diet" by increasing PPAR $a$ and $\gamma$ expression and reducing TC, MMP-9, and Cat S levels. Acta Pharmacol Sin 2010, 31(10):1350-8.

87. Braun A, Rigotti A, Trigatti BL: Myocardial infarction following atherosclerosis in murine models. Curr Drug Targets 2008, 9(3):217-23.

88. French CJ, Zaman AK, Sobel BE: Cardiac fibrosis and diastolic dysfunction after myocardial infarction in apolipoprotein E knockout mice. Coron Artery Dis 2009, 20(7):479-82.

89. Calara F, Silvestre M, Casanada F, Yuan N, Napoli C, Palinski W: Spontaneous plaque rupture and secondary thrombosis in apolipoprotein E-deficient and LDL receptor-deficient mice. J Pathol 2001, 195(2):257-63.

90. Onozuka H, Fujii S, Mikami T, Yamada S, Ishimori N, Shimizu T, Furumoto T, Nakai Y, Komuro K, Nishihara K, Okamoto H, Kitabatake A: In vivo echocardiographic detection of cardiovascular lesions in apolipoprotein E-knockout mice using a novel high-frequency high-speed echocardiography technique. Circ J 2002, 66(3):272-6.

91. Wang YX, Halks-Miller M, Vergona R, Sullivan ME, Fitch R, Mallari C, MartinMcNulty B, da Cunha V, Freay A, Rubanyi GM, Kauser K: Increased aortic stiffness assessed by pulse wave velocity in apolipoprotein E-deficient mice. Am J Physiol Heart Circ Physiol 2000, 278(2):H428-34.

92. Vincelette J, Martin-McNulty B, Vergona R, Sullivan ME, Wang YX: Reduced cardiac functional reserve in apolipoprotein E knockout mice. Trans/ Res 2006, 148(1):30-6.

93. Zaragoza C, Gomez-Guerrero C, Martin-Ventura JL, Blanco-Colio L, Lavin B, Mallavia B, Tarin C, Mas S, Ortiz A, Egido J: Animal models of cardiovascular diseases. J Biomed Biotechnol 2011, 2011:497841.

94. Sabharwal R, Weiss RM, Stauss HM, Sigmund CD, Abboud FM Chapleau MW: ApoE $/ \mathrm{R}^{+} \mathrm{A}^{+}$mice with hypercholesterolemia, hypertension, and decreased baroreflex sensitivity spontaneously develop heart failure with age. FASEB J 2007, 21:753.14.

doi:10.1186/1423-0127-19-22

Cite this article as: Vasquez et al.: Cardiac and vascular phenotypes in the apolipoprotein E-deficient mouse. Journal of Biomedical Science 2012 19:22.

\section{Submit your next manuscript to BioMed Central and take full advantage of:}

- Convenient online submission

- Thorough peer review

- No space constraints or color figure charges

- Immediate publication on acceptance

- Inclusion in PubMed, CAS, Scopus and Google Scholar

- Research which is freely available for redistribution

Submit your manuscript at www.biomedcentral.com/submit
Biomed Central 